\title{
Sorption of uranium(VI) onto montmorillonite in the presence of calcite
}

\author{
B. URICK ${ }^{1}$, A. C. ShaW ${ }^{1}$, D. Q. LA ${ }^{1}$, \\ A. Gutierrez Diaz ${ }^{1}$, C. TOURnASSAT ${ }^{2,3}$, \\ R. M. TINNACHER ${ }^{1, *}$ \\ ${ }^{1}$ California State University East Bay, Hayward, CA 94542 \\ (*correspondance: Ruth.Tinnacher@ecsueastbay.edu) \\ ${ }^{2}$ Lawrence Berkeley National Lab, Berkeley, CA 94720 \\ ${ }^{3}$ UMR 7327 Institut des Sciences de la Terre d'Orléans, \\ Université d'Orléans - CNRS/INSU - BRGM, Orléans
}

Plans for nuclear waste disposal involve the design of engineered barrier systems to minimize the release of radioactive contaminants from waste canisters. Engineered barrier systems include the buffer material bentonite, mostly consisting of montmorillonite clay. Montmorillonite provides cation exchange sites located on basal clay surfaces as well as surface complexation sites on the edges of clay particles for radionuclide sorption. Calcite is a relevant mineral impurity in bentonite, since it could affect the sorption of uranium(VI) (U(VI)) onto montmorillonite in multiple ways. First, calcite provides an additional surface for U(VI) sorption reactions. In addition, calcite dissolution will lead to dissolved $\mathrm{Ca}$ in porewater solutions, which may in turn affect U(VI) solution speciation, U(VI) ion exchange reactions, and the interlayer spacing of smectite layers.

In order to study the effects of calcite and dissolved $\mathrm{Ca}$ on U(VI) sorption onto montmorillonite, we performed benchtop experiments over a range of chemical solution conditions $(\mathrm{pH}$ 2.5-8.5, ITotal $=0.01 \mathrm{M}$ and $0.1 \mathrm{M}$, $\mathrm{U}(\mathrm{VI})_{\mathrm{Total}}=1 \mathrm{E}-6$ and $\left.1 \mathrm{E}-7 \mathrm{M}\right)$. At low $\mathrm{pH}$ and ionic strength, the presence of dissolved calcium resulted in decreased U(VI) sorption onto montmorillonite. This trend can be explained by the preferential binding of $\mathrm{Ca}^{2+}$ cations relative to $\mathrm{UO}_{2}{ }^{2+}$, which resulted in a competition between the two cations for cation exchange sites. Our hypothesis is further supported by the results of additional sorption experiments, performed at various ionic strengths but in the absence of $\mathrm{Ca}$. At higher $\mathrm{pH}$ values, there also appears to be a slight decrease in U(VI) sorption, most likely due to the formation of ternary calciumuranyl-carbonato complexes in solution. Additional experiments will include mixtures of calcite and montmorillonite as solids. Overall, these results will allow us to assess $\mathrm{U}(\mathrm{VI})$ sorption in future engineered barrier systems, while taking into account the effects of calcite impurities under relevant repository conditions.

This research is funded through DOE's Nuclear Energy University Program. 